\title{
Intragastric balloons in high-risk obese patients in a Brazilian center: initial experience
}

\section{Balões intragástricos em obesos de alto risco em um centro brasileiro: experiência inicial}

\author{
Alana Costa Borges ${ }^{1}$; Paulo César Almeida 3 ; Stella M. T. Furlani2; Marcelo de Sousa Cury4; Shantanu Gaur ${ }^{5}$
}

\begin{abstract}
A B S T R A C T
Objective: to assess the short-term efficacy, tolerance and complications in high-risk morbidly obese patients treated with an intragastric balloon as a bridge for surgery. Methods: we conducted a post-hoc analysis study in a Brazilian teaching hospital from 2010 to 2014, with 23 adult patients with a BMI of $48 \mathrm{~kg} / \mathrm{m}^{2}$, who received a single intragastric air or liquid balloon. We defined efficacy as $10 \%$ excess weight loss, and complications, as adverse events consequent to the intragastric balloon diagnosed after the initial accommodative period. We expressed the anthropometric results as means \pm standard deviation, comparing the groups with paired T / Student's $T$ tests, when appropriate, with $p<0.05$ considered statistically significant. Results: the balloons were effective in $91.3 \%$ of the patients, remained in situ for an average of 5.5 months and most of them (65.2\%) were air-filled, with a mean excess weight loss of $23.7 \mathrm{~kg} \pm 9.7$ (excess weight loss $21.7 \% \pm 8.9)$ and mean BMI reduction of $8.3 \mathrm{~kg} / \mathrm{m}^{2} \pm 3.3$. Complications $(17.3 \%)$ included abdominal discomfort, balloon deflation and late intolerance, without severe cases. Most of the participants (82.7\%) did not experience adverse effects. We removed the intragastric balloons in time, without intercurrences, and $52.2 \%$ of these patients underwent bariatric surgery within one month. Conclusion: in our center, intragastric balloons can be successfully used as an initial weight loss procedure, with good tolerance and acceptable complications rates.
\end{abstract}

Keywords: Gastric Balloon. Risk. Obesity, Morbid. Bariatric Surgery.

\section{INTRODUCTION}

$\mathrm{O}$ besity is an international health problem, with high morbidity and mortality ${ }^{1}$. Worldwide, more than two million people die annually due to obesity or overweight ${ }^{2}$. The higher the body mass index (BMI), the greater the risk of comorbidities ${ }^{2}$. Overall, mean BMI has increased by $0.4 \mathrm{~kg} / \mathrm{m}^{2}$ per decade ${ }^{3}$. In Brazil, obesity affects $17.5 \%$ of the population and the prevalence of morbid obesity $\left(\mathrm{BMl} \geq 40 \mathrm{~kg} / \mathrm{m}^{2}\right.$ ) increased by more than $255 \%$ since $1970 s^{4,5}$.

Health spending rises in direct proportion to the BMI as well. In 2011, Brazilian morbid obesity costs (US\$ 64.2 million) corresponded to $23.8 \%$ of all expenses related to obesity (US\$269.6 million)2 ${ }^{2}$. Theoretically, a decrease of only $1 \%$ in the mean BMI can potentially lead to a substantial reduction in the national economic burden imposed by obesity ${ }^{6}$.

Extreme obesity is associated with a large decrease in life expectancy when compared to that of normal weight individuals, and the main causes of death are heart disease, cancer and diabetes. When calculating the years of life lost, the numbers are worrisome: in the BMI range of $40-45 \mathrm{~kg} / \mathrm{m}^{2}$, mean survival decreases by 6.5 years, of $50-55 \mathrm{~kg} / \mathrm{m}^{2}$, in 9.8 years, and in the range of $55-60 \mathrm{~kg} / \mathrm{m}^{2}$, in 13.7 years ${ }^{7}$.

High-risk morbid obese individuals are usually defined by superobesity (SO), BMl $=50 \mathrm{~kg} / \mathrm{m}^{2}$, associated with males, age $>45$ years and presence of severe comorbidities. Such a population represents a challenge in bariatric surgery due to technical difficulties, high mortality rates, and perioperative morbidity, which reach

1 - Zilda Arns Hospital and Maternity, Digestive Endoscopy Department, Fortaleza, CE, Brazil. 2 - César Cals General Hospital, Digestive Endoscopy Department, Fortaleza, CE, Brazil. 3 - State University of Ceará, Biostatistics, Health Sciences Center, Fortaleza, CE, Brazil. 4 - SCOPE Endoscopy Unit, Digestive Endoscopy, Campo Grande, MS, Brazil. 5 - Allurion Technologies, Wellesley, MA, USA. 
$12 \%$ and $40 \%$, respectively, in the early postoperative period $^{8}$. In fact, the 30-day mortality risk increases exponentially according to the number of comorbidities in these patients: $0-1$ comorbidities: $0.03 \%$; 2-3 comorbidities; 0,16\%; and 4 comorbidities: 7,4 \% ${ }^{9}$.

To minimize this risk, a significant loss of preoperative weight is essential. Currently, the viable strategies to achieve it are hypocaloric diet, medications, hospitalization and Intragastric Balloon (IGB) $)^{8,10}$. However, the low calorie diet has a considerable circumvention rate, most anti-obesity drugs have been withdrawn from the market due to systemic side effects and hospitalization for an intensive program in a controlled environment is excessively onerous ${ }^{10}$. Thus, IGB have been widely used as a bridge for bariatric surgery in high-risk superobese patients. Generally, the established goal is $10 \%$ excess weight loss $(10 \% \mathrm{EWL})^{10}$, with positive effects on postoperative risk, technical complexity and shorter surgical times due to a decrease in the volume of the liver and adipose, subcutaneous and visceral tissues ${ }^{11}$, and may improve the results of surgery after one year ${ }^{12}$. The degree of risk reduction seems to relate to the degree of weight loss, and patients with higher BMls probably benefit more ${ }^{13}$.

In six months, IGB generally reach the goal of $10 \% \mathrm{EWL}$ or more, providing greater control of obesity-related diseases and improvement in metabolic profile, without compensatory increase of appetite hormones ${ }^{10,14-16}$. In fact, it is considered a safe procedure with few complications. Serious events are exceptional ${ }^{17}$. Perforation, the most feared, can occur in the stomach $(0.2 \%)$ or more rarely in the esophagus, subsequent to implantation or endoscopic extraction ${ }^{18-20}$. Intestinal obstruction is estimated at $0.2 \%{ }^{18}$. The main adverse effect is vomiting, especially in the first days postprocedure ${ }^{21}$. Additionally, there are reports of esophagitis and gastritis diagnosed after its removal ${ }^{22}$.

Absolute contraindications to the use of IGB are previous gastric surgery, large hiatal hernias $(\geq 5 \mathrm{~cm})$, pregnancy, potential hemorrhagic lesions in the upper gastrointestinal tract, coagulation disorders and severe liver diseases. Relative contraindications include previous abdominal surgery, esophagitis, Crohn's disease and psychiatric disorders ${ }^{23}$.
In this study, our objective is to identify the short-term efficacy of IGB in the treatment of high-risk morbid obesity patients in a bridge-to-surgery strategy, assessing their tolerance and complications at our center.

\section{METHODS}

This is a post-hoc study-analysis from June 2010 to June 2014, at a public hospital in Fortaleza-CE. The institutional Ethics Committee approved the research protocol (Number 831,224), with written consent of the patients and the hospital for access to medical records. Participants included high-risk, morbidly obese adult patients who were refractory to conservative treatment, were involved in the weight loss program, and underwent IGB insertion as a bridge to bariatric surgery. We excluded individuals with $\mathrm{BMl}<48 \mathrm{~kg} / \mathrm{m}^{2}$ or with balloon contraindications.

Each patient received a single balloon, which could be filled with $500 \mathrm{cc}$ of air or 500-700 cc of liquid. Until October 2012, we implanted air IGB, and liquid ones thereafter, due to changes in the availability of these devices in the hospital. The insertion of IGB occurred with conscious sedation assisted by an anesthesiologist and removal under general anesthesia under direct endoscopic control, using gastroscopes and standard accessories (needle catheter, grasping clamps and polypectomy loops). We performed a routine upper digestive endoscopy before IGB implantation.

The preoperative weight loss protocol consisted of multidisciplinary outpatient follow-up (with surgeons, internists, nutritionists, psychologists and psychiatrists), IGB implantation, hypocaloric diet (1000 cal/day) and physical activities. In addition, there were regular consultations with the bariatric endoscopist for assessment of efficacy and tolerance, weekly in the first month post-procedure, fortnightly in the second month, and monthly thereafter. We prescribed proton pump inhibitors during the IGB permanence, associated with antiemetics and analgesics during the first two weeks.

All patients had their weight monitored before IGB implantation, at each follow-up visit and at extraction. Using standard methods of weight loss quantification ${ }^{24}$, such as Ideal weight corresponding to BMI $25 \mathrm{~kg} / \mathrm{m}^{2}$ and $\%$ EWL, we defined the efficacy as at least 10\% EWL. 
We considered complications as adverse and expressed results as mean \pm standard deviation. We effects attributable to IGB diagnosed after two weeks used the paired T and Student's T tests, as appropriate, of insertion, identified during the outpatient follow-up. for comparison between groups. We set the statistical In our experience, nausea, vomiting and abdominal pain are very common in such a period, consequent to gastric accommodation to the foreign body, and easily treated with oral medication. Therefore, we did not consider such complications in this study.

The studied variables included IGB type, length of stay, associated complications, \% EWL, weight variation and BMI. We used used SPSS 20 to process the data, significance at $p<0.05$.

\section{RESULTS}

Twenty-three patients received IGB and their characteristics are shown in table 1. The main comorbidities at the beginning of treatment were hypertension, sleep apnea syndrome and diabetes.

Table 1. Characteristics of high-risk patients with morbid obesity treated with IGB as bridge to bariatric surgery.

\begin{tabular}{lccc}
\hline & $N$ & $\%$ & Mean \pm SD \\
\hline Age (years) & 23 & 100 & $40.8 \pm 11.4$ \\
$\begin{array}{l}\text { 19-67 } \\
\text { Gender }\end{array}$ & 12 & 52.2 & \\
$\quad$ Male & 11 & 47.8 & \\
$\quad$ Female & & & \\
\hline Number of Comorbidities & 7 & 30.4 & \\
0 & 5 & 21.8 & \\
1 & 4 & 17.4 & \\
2 & 7 & 30.4 & \\
3 & & & \\
\hline Practice of physical activity & 8 & 34.8 & \\
Yes & 15 & 65.2 & \\
No & & & \\
\hline IGB Type & 15 & 65.2 \\
Air & 8 & 34.8 \\
Liquid & & & \\
\hline
\end{tabular}

SD: standard deviation.

The IGB stayed for an average time of $5.5 \mathrm{~m}^{2}$. All anthropometric parameters, before and after months and most of them (65.2\%) were air-filled, with a IGB, displayed statistically significant differences, with mean weight loss of $23.6 \mathrm{~kg}(21.7 \% \mathrm{EWL})$, with maximum $\quad \mathrm{p}<0.0001$. Table 2 shows such results. $41 \mathrm{~kg}(35.8 \% \mathrm{EWL})$. BMI reduced on average $8.3 \mathrm{~kg} /$ 
Table 2. Anthropometric parameters in high-risk, morbidly obese individuals before and after the use of the IGB.

\begin{tabular}{|c|c|c|c|c|}
\hline & Before & After & Weight loss results & $p$ \\
\hline $\begin{array}{l}\text { Weight }(\mathrm{kg}) \\
(\mathrm{mean} \pm \mathrm{SD})\end{array}$ & $\begin{array}{c}175.3 \pm 33.1 \\
{[122-238]}\end{array}$ & $\begin{array}{c}151.6 \pm 31.0 \\
{[97-214]}\end{array}$ & & $<0.0001$ \\
\hline $\begin{array}{l}\mathrm{EW}(\mathrm{kg}) \\
(\mathrm{mean} \pm \mathrm{SD})\end{array}$ & $\begin{array}{c}112.0 \pm 26.0 \\
{[73.6-168.4]}\end{array}$ & $\begin{array}{l}88.3 \pm 24.9 \\
{[48-136.1]}\end{array}$ & & $<0.0001$ \\
\hline $\begin{array}{l}\text { BMI }\left(\mathrm{kg} / \mathrm{m}^{2}\right) \\
(\mathrm{mean} \pm \mathrm{SD})\end{array}$ & $\begin{array}{l}61.7 \pm 7.5 \\
{[48-78.6]}\end{array}$ & $\begin{array}{c}53.4 \pm 7.8 \\
{[40.6-68.6]}\end{array}$ & & $<0.0001$ \\
\hline $\begin{array}{l}\text { BMl reduction }\left(\mathrm{kg} / \mathrm{m}^{2}\right) \\
(\mathrm{mean} \pm \mathrm{SD})\end{array}$ & & & $\begin{array}{c}8.3 \pm 3.3 \\
{[1.5-14.0]}\end{array}$ & \\
\hline $\begin{array}{l}\text { Weight loss }(\mathrm{kg}) \\
(\text { mean } \pm \text { SD) }\end{array}$ & & & $\begin{array}{c}23.7 \pm 9.7 \\
{[4.3-41]}\end{array}$ & \\
\hline $\begin{array}{l}\% \text { EWL } \\
(\text { mean } \pm S D)\end{array}$ & & & $\begin{array}{l}21.7 \pm 8.9 \\
{[3.5-35.8]}\end{array}$ & \\
\hline $\begin{array}{l}\text { IGB time (months) } \\
\text { (mean } \pm \text { SD) }\end{array}$ & & $\begin{array}{c}5.5 \pm 1.4 \\
{[1-7]}\end{array}$ & & \\
\hline
\end{tabular}

SD: standard deviation; EW: excess weight; EWL: excess weight loss.

The effectiveness of the balloons in our center was $91.3 \%$. All, except for two participants, were clinically successful, exceeding the 10\% EWL target. The first failure occurred in a female patient who, despite a time with IGB of seven months, reached only 3.5\% EWL $(4.3 \mathrm{~kg})$ and a BMI variation of $1.5 \mathrm{~kg} / \mathrm{m}^{2}$. She did not adhere to the prescription of physical activity, nor to the low-calorie diet. The other failure occurred in a man with satisfactory adherence to the combined treatment during the six months. However, he obtained 9\% EWL (13.5kg) and a BMI reduction of $4.0 \mathrm{~kg} / \mathrm{m}^{2}$.

Given our small sample, the comparison tests performed did not reach statistical significance. However, there was a tendency for better EWL results in older patients, in the 40-67 years age range (23.1\% EWL vs. $20.3 \% \mathrm{EWL}, \mathrm{p}=0.465)$, who were physically active (22.3\% EWL vs. $21.3 \% \mathrm{EWL}, \mathrm{p}=0.820$ ) and with more comorbidities (24.6\% EWL vs. $22.05 \%$ EWL, $\mathrm{p}=0.842$ ). There was no difference between the two types of balloons in relation to the final weight parameters.

As described in table 3, our complication rate was $17.3 \%$, including abdominal discomfort (8.7\%), balloon deflation with migration (4.3\%), and late intolerance with severe dehydration (4.3\%).
Table 3. Intragastric balloon complications in high-risk, morbidly obese patients.

\begin{tabular}{lcc}
\hline \multicolumn{1}{c}{ Complications } & $\mathrm{N}$ & $\%$ \\
\hline Abdominal discomfort & 2 & 8.7 \\
IGB deflation/obstruction & 1 & 4.3 \\
Late intolerance/dehydration & 1 & 4.3 \\
No complications & 19 & 82.7 \\
Total & 23 & 100 \\
\hline
\end{tabular}

Cases of abdominal discomfort were mild, patients were treated conservatively and experienced gradual symptom resolution. On the other hand, the patient with balloon deflation had migration to the small intestine and obstruction, being submitted to surgery for removal of the device. Interestingly, the IGB had remained in situ during the six-month period. One late intolerance occurred after one month of fluid IGB use and the patient developed intense and refractory vomiting, aggravated by dehydration and acute renal failure. Treatment included hospitalization and balloon extraction. Bariatric surgery was performed during the same admission, after normalization of clinical parameters. Nevertheless, 18.9\% EWL $(20 \mathrm{~kg})$ was achieved preoperatively.

In $82.7 \%$ of patients, there were no complications and their IGBs were extracted when 
programmed, without any technical difficulties described by endoscopists. The majority of patients (52.2\%) underwent bariatric surgery (Roux-en-Y gastric bypass) within one month after balloon extraction. The remainder were submitted to surgery after this interval, following the schedule of bariatric surgeons.

\section{DISCUSSION}

There are several studies of IGBs with heterogeneity in BMI the selection criteria. Most of them define the lower limit of BMl at $40 \mathrm{~kg} / \mathrm{m}^{2}$, with weight losses ranging from 17 to $21 \mathrm{~kg}^{16,25-28}$. Much of the published data refers to Orbera's IGB, while there is a relative paucity of articles on Heliosphere ${ }^{29}$, a $30 \mathrm{~g}$ silicone-coated polymer with two layers interconnected by a valve, unlike most liquid IGBs, which are also made of silicone but weigh 500-600 $\mathrm{g}^{23,30}$. The Medicone IGB, which used in this study, requires further investigation, with little clinical data so far.

Experiments with the Heliosphere (air IGB) report weight losses of around $17 \mathrm{~kg}$. Its tolerance, efficacy and final results are equivalent to those of Orbera in a small series of cases $^{30-35}$, a finding that was also demonstrated in two controlled studies comparing both IGB, where there was no significant difference in the weight loss final parameters ${ }^{36,37}$. Likewise, our cohort did not find statistical difference between the two balloons in the final anthropometric parameters. However, technical problems with air IGB are repeatedly emphasized in the studies: considerable rates of spontaneous deflation, difficult removal due to valve size, longer extraction times, patient discomfort, laborious passage through the cardia or lower pharynx, and occasional need for more complex procedures such as rigid esophagoscopy or surgery ${ }^{30,31,33,36,37}$. Unlike the international literature, our endoscopists did not describe any technical challenges in the withdrawal and we believe that the reason was the previous extensive experience of the team with the use of IGB.

Compared with previous data, we reported greater weight loss, with a mean of $23.6 \mathrm{~kg}(21.7 \% \mathrm{EWL})$, a maximum of $41 \mathrm{~kg}(35.8 \% \mathrm{EWL})$ and a mean $\mathrm{BMI}$ decrease of $8.3 \mathrm{~kg} / \mathrm{m}^{2}$. We believe that the greater initial weight, our multidisciplinary program with regular follow- up and the motivation of the participants contributed to these results. In addition, correlating with a national multicenter study that described a mean BMI decrease of $8.5 \mathrm{~kg} / \mathrm{m}^{2}$ and $26.1 \mathrm{~kg} \mathrm{EWL}(23.5 \% \mathrm{EWL})$ in the superobese sample $^{38}$. Our numbers are quite similar.

The weight loss results were excellent in 21 of the 23 patients (91.3\% efficacy), with an average treatment duration of 5.5 months. Recently, Gaur et al. ${ }^{39}$ have shown that IGB appear to be more effective in the first trimester of therapy, with mean results corresponding to $80 \%$ of the total amount lost. Current research has not explored the monthly kinetics of weight loss. However, this may represent a justification for shifting the sixmonth treatment paradigm.

This study showed a trend towards greater weight loss in older patients, exercise practitioners and patients with more comorbidities. Physical activity plays an important role in bariatric patients' care, with recent evidence demonstrating that higher levels of pre and postoperative activity are associated with greater weight loss ${ }^{40}$. Elderly patients with severe comorbidities such as diabetes have a high probability of weight loss ${ }^{41}$.

Our overall complication rate was $17.3 \%$. The literature cites a range of possible complications: intolerance with early removal (up to 6.3\%), deflation and migration (1.6-28.9\%), abdominal pain (5.8-11.6\%), nausea and vomiting (up to 18\%), minor side effects $(0.2-1.27 \%)$ and some rare reports of fatalities $(0.07 \%)^{23,30,39,42}$. In our study, we observed a $4.3 \%$ rate (one participant) of late intolerance, resolved upon device removal. Many authors consider vomiting intrinsic to balloon use, especially in the early stages. Its appearance occurs within hours, persisting for a few days after placement, as a consequence of the natural adaptation of the stomach to the foreign body ${ }^{43}$. Thus, intolerance is characterized by vomiting that persists for longer periods, usually associated with abdominal discomfort. These unpleasant symptoms can lead to patient dissatisfaction or lack of motivation to continue therapy. At the same time, patients who do not experience these symptoms may refuse to follow dietary modifications, culminating in weight loss below the expected level ${ }^{43}$. However, when intense enough (hyperemesis), vomiting may trigger a dangerous sequence of electrolyte imbalance/ dehydration/ renal failure, characterizing the indication 
for IGB withdrawal if refractory to conservative treatment ${ }^{43,44}$. This chain of events happened in our patient, leading the authors to opt for the early removal of IGB. On the other hand, our two participants (8.7\%) with abdominal discomfort evolved successfully with conservative treatment.

We had one case $(4.3 \%)$ of spontaneous IGB deflation, complicated by intestinal migration and obstruction. Deflation is a well-known phenomenon, common to all existing types of balloons. The only postulated risk factor is implant permanence exceeding the recommended withdrawal date, with greater susceptibility to device dysfunction and leakage ${ }^{39}$. The longer it remains in situ, the greater the likelihood of damage, such as erosions on the silicone surface ${ }^{43}$. Diagnosing a leakage of liquid IGB is relatively simple, given the urine of bluish coloration, because of the excretion of methylene blue. However, diagnosing the spontaneous rupture of an air IGB is a challenge, since it is usually an asymptomatic process. Frequently, one can only detect subsequent complications, such as mechanical ileus or perforations ${ }^{45}$.

In conclusion, the current efficacy of intragastric balloons in high-risk obese patients at our center is $91.3 \%$, with clinical success and satisfactory tolerance. Our complication profile is within published rates. Intragastric balloons can be used effectively, in association with diet, as a bridge to surgery in our center.

\title{
R E S U M O
}

\begin{abstract}
Objetivo: identificar a eficácia em curto prazo, a tolerância e as complicações em obesos mórbidos de alto risco, tratados com balão intragástrico como ponte para cirurgia. Métodos: estudo de análise post-hoc em um hospital acadêmico brasileiro durante o período de 2010 a 2014, de 23 pacientes adultos com IMC de 48kg/m² que receberam um único balão intragástrico de ar ou líquido. Eficácia foi definida como perda de excesso de peso de 10\%, e complicações como eventos adversos consequentes ao balão intragástrico diagnosticados após o período acomodativo inicial. Expressaram-se os resultados antropométricos com média \pm desvio padrão, comparando os grupos com testes T Pareado / T de Student, quando apropriado, com $p<0,05$ considerado estatisticamente significante. Resultados: os balões foram efetivos em 91,3\% dos pacientes, permaneceram in situ por em média 5,5 meses e a maioria deles $(65,2 \%)$ era de ar, com perda média de excesso peso de $23,7 \mathrm{~kg} \pm 9,7$ (perda de excesso de peso de $21,7 \% \pm 8,9$ ) e redução média de IMC de 8,3kg/m² $\pm 3,3$. As complicações (17,3\%) compreenderam desconforto abdominal, deflação do balão e intolerância tardia, sem casos graves. A maioria dos participantes $(82,7 \%)$ não experimentou efeitos adversos, seus balões intragástricos foram extraídos em tempo, sem intercorrências e $52,2 \%$ desses pacientes submeteram-se à cirurgia bariátrica no intervalo de um mês. Conclusão: no nosso centro, balões intragástricos podem ser usados com sucesso como procedimento inicial de perda ponderal, com boa tolerância e taxas aceitáveis de complicações.
\end{abstract}

Descritores: Balão Gástrico. Risco. Obesidade Mórbida. Cirurgia Bariátrica.

\section{REFERENCES}

1. ASGE Standards of Practice Committee, Anderson MA, Gan SI, Fanelli RD, Baron TH, Banerjee S, Cash BD, Dominitz JA, Harrison ME, Ikenberry SO, Jagannath SB, Lichtenstein DR, Shen B, Lee KK, Van Guilder T, Stewart LE. Role of endoscopy in the bariatric surgery patient. Gastrointest Endosc. 2008;68(1):1-10.

2. Oliveira ML, Santos LM, da Silva EN. Direct healthcare cost of obesity in Brazil: an application of the cost-ofillness method from the perspective of the public health system in 2011. PLoS ONE. 2015;10(4):e0121160.

3. Sturm H, Hattori A. Morbid obesity rates continue to rise rapidly in the United States. Int J Obes (Lond). 2013;37(6):889-91.

4. Brasil. Ministério da Saúde. Secretaria de Vigilância em Saúde. Vigitel Brasil 2013: vigilância de fatores de risco e proteção para doenças crônicas por inquérito telefônico. Brasília: Ministério da Saúde; 2014.

5. Santos LM, de Oliveira IV, Peters LR, Conde WL. Trends in morbid obesity and in bariatric surgeries covered by the Brazilian public health system. Obes Surg. 2010;20(7):943-8.

6. Rtveladze K, Marsh T, Webber L, Kilpi F, Levy D, Conde $W$, et al. Health and economic burden of obesity in Brazil. PLoS One. 2013;8(7):e68785. 
7. Kitahara $C M$, Flint $A J$, Berrington de Gonzalez $A B$, Bernstein L, Brotzman M, Maclnns RJ, et al. Association between class III obesity (BMI of 40-59 kg/m2) and mortality: a pooled analysis of 20 prospective studies. PLoS Med. 2014;11(7):e1001673.

8. Spyropoulos C, Katsakoulis E, Mead N, Vagenas K, Kalfarentzos F. Intragastric balloon for highrisk super-obese patients: a prospective analysis of efficacy. Surg Obes Relat Dis. 2007;3(1):78-83.

9. Khan MA, Grinberg R, Johnson S, Afthinos JN, Gibbs KE. Perioperative risk factors for 30-day mortality after bariatric surgery: is functional status important? Surg Endosc. 2013;27(5):1772-7.

10. Santo MA, Riccioppo D, Pajecki D, Cleva R, Kawamoto $\mathrm{F}$, Cecconello I. Preoperative weight loss in superobese patients: study of the rate of weight loss and its effects on surgical morbidity. Clinics (Sao Paulo). 2014;69(12):828-34.

11. Collins J, McCloskey C, Titchner R, Goodpaster B, Hoffman M, Hauser $D$, et al. Preoperative weight loss in high-risk superobese bariatric patients: a computed tomography-based analysis. Surg Obes Relat Dis. 2011;7(4):480-5.

12. Giordano S, Victorzon M. The impact of preoperative weight loss before laparoscopic gastric bypass. Obes Surg. 2014;24(5):669-74.

13. Anderin C, Gustafsson UO, Heijbel N, Thorell A. Weight loss before bariatric surgery and postoperative complications: data from the Scandinavian Obesity Registry (SOReg). Ann Surg. 2015;261(5):909-13.

14. Fuller NR, Lau NS, Denyer G, Caterson ID. An intragastric balloon produces large weight losses in the absence of change in ghrelin or peptide YY. Clin Obes. 2013;3(6):172-9.

15. Forlano R, Ippolito AM, lacobellis A, Merla A, Valvano MR, Niro $G$, et al. Effect of the BioEnterics intragastric balloon on weight, insulin resistance and liver steatosis in obese patients. Gastrointest Endosc. 2010;71(6):927-33.

16. Carvalho MR, Jorge Z, Nobre E, Dias T, CortezPinho $H$, Machado MV, et al. [Intragastric balloon in the treatment of morbid obesity]. Acta Med Port. 2011;24(4):489-98. Portuguese.

17. Fernandes $M$, Atallah AN, Soares BG, Humberto $S$, Guimarães $S$, Matos $D$, et al. Intragastric balloon for obesity. Cochrane Database Syst Rev. 2007;(1):CD004931.

18. Dumonceau JM. Evidence-based review of the BioEnterics intragastric balloon for weight loss. Obes Surg. 2008;18(12):1611-7.

19. Koutelidakis I, Dragoumis D, Papaziogas B, Patsas A, Katsougianopoulos A, Atmatzidis S, et al. Gastric perforation and death after the insertion of an intragastric balloon. Obes Surg. 2009;19(3):393-6.

20. Ruiz D, Vranas K, Robinson DA, Salvatore L, Turner JW, Adsati T. Esophageal perforation after gastric balloon extraction. Obes Surg. 2009;19(2):257-60.

21. Imaz I, Martínez-Cervell C, García-Álvarez EE, SendraGutiérrez JM, González-Enríquez J. Safety and effectiveness of the intragastric balloons for obesity. A meta-analysis. Obes Surg. 2008;18(7):841-6.

22. Mathus-Vliegen EM, Tytgat GN, VeldhuyzenOffermans EA. Intragastric balloons in the treatment of super-morbid obesity. Double-blind, shamcontrolled, crossover evaluation of 500-milliliter balloon. Gastroenterology. 1990;99(2):362-9.

23. Swidnicka-Siergiejko A, Wróblewski E, Dabrowski A. Endoscopic treatment of obesity. Can J Gastroenterol. 2011;25(11):627-33.

24. Baltasar A, Perez N, Serra C, Bou R, Bengochea $M$, Borrás F. Weight loss reporting: predicted body mass index after bariatric surgery. Obes Surg. 2011;21(3):367-72.

25. Mathus-Vliegen EM, Alders PR, Chuttani R, Scherpenisse J. Outcomes of intragastric balloon placements in a private practice setting. Endoscopy. 2015;47(4):302-7.

26. Doldi SB, Micheletto G, Perrini MN, Librenti MC, Rella $\mathrm{S}$. Treatment of morbid obesity with intragastric balloon in association with diet. Obes Surg. 2002;12(4):583-7.

27. Almeida N, Gomes D, Gonçalves C, Gregório C, Brito D, Campos JC, et al. [Intragastric balloon in the grave forms of obesity]. J Port Gastroenterol. 2006; 13(5):220-5. Portuguese.

28. Bispo M, Ferreira da Silva MJ, Bana T, Seves I, Couto $\mathrm{G}$, Peixe $\mathrm{P}$, et al. [Intragastric balloon in the treatment of obesity: evaluation of efficacy, safety and tolerability]. GE J Port Gastroenterol. 2008;15(3):1039. Portuguese. 
29. Tsesmeli N, Coumaros D. Review of endoscopic devices for weight reduction: old and new balloons and implantable prostheses. Endoscopy. 2009; 41(12):1082-9.

30. Martínez Olmos MÁ, Cancer E, Bretón I, Álvarez V, Abilés V, Abilés J, Peláez N, Mellado C, Mazure RA, Culebras JM; Grupo de Trabajo OBESMINVA de la SENPE. [Intragastric balloon: a review concerning alternative balloons compared to the classical ones (Bioenterics)]. Nutr Hosp. 2015;31(1):84-91. Spanish.

31. Forestieri $P$, De Palma GD, Formato A, Giuliano ME, Monda A, Pilone $V$, et al. Heliosphere Bag in the treatment of severe obesity: preliminary experience. Obes Surg. 2006;16(5):635-7.

32. Sciumè $C$, Geraci G, Pisello F, Arnone E, Mortillaro $M$, Modica $G$. [Role of intragastric air filled balloon (Heliosphere Bag) in severe obesity. Personal experience]. Ann Ital Chir. 2009;80(2):113-7. Italian.

33. Trande P, Mussetto A, Mirante VG, De Martinis E, Olivetti G, Conigliaro RL, et al. Efficacy, tolerance and safety of the new intragastric air-filled balloon (Heliosphere Bag) for obesity: the experience of 17 cases. Obes Surg. 2010;20(9):1227-30.

34. Lecumberri E, Krekshi W, Matía P, Hermida C, de la Torre NG, Cabrerizo L, et al. Effectiveness and safety of air-filled baloon Heliosphere $B A G \circledast$ in 82 consecutive obese patients. Obes Surg. 2011;21(10):1508-12.

35. Giuricin M, Nagliati C, Palmisano S, Simeth C, Urban $F$, Buri $L$, et al. Short- and long-term efficacy of intragastric air-filled balloon (Heliosphere ${ }^{\circledR}$ BAG) among obese patients. Obes Surg. 2012;22(11):1686-9.

36. De Castro ML, Morales MJ, Del Campo V, Pineda JR, Pena E, Sierra JM, et al. Efficacy, safety and tolerance of two types of intragastric balloons placed in obese subjects: a double-blind comparative study. Obes Surg. 2010;20(12):1642-6.

37. Giardiello C, Borrelli A, Silvestri E, Antognozzi V, lodice G, Lorenzo M. Air-filled vs water-filled intragastric balloon: a prospective randomized study. Obes Surg. 2012;22(12):1916-9.

38. Sallet JA, Marchesini JB, Paiva DS, Komoto K, Pizani $\mathrm{CE}$, Ribeiro ML, et al. Brazilian multicenter study of the intragastric balloon. Obes Surg. 2004;14(7):991-8.

39. Gaur S, Levy S, Mathus-Vliegen L, Chuttani R. Balancing risk and reward: a critical review of the intragastric balloon for weight loss. Gastrointest Endosc. 2015;81(6):1330-6.

40. King WC, Bond DS. The importance of preoperative and postoperative physical activity counseling in bariatric surgery. Exerc Sport Sci Rev. 2013;41(1):2635.

41. Calderón-Larrañaga $A$, Hernández-Olivan $P$, González-Rubio F, Gimeno-Feliu LA, Poblador-Plou $B$, Prados-Torres A. Multimorbidity and weight loss in obese primary care patients: longitudinal study based on electronic healthcare records. BMJ Open. 2015;5(3):e006227.

42. ASGE Technology Committee, Kethu SR, Banerjee S, Barth BA, Desilets DJ, Kaul V, Pedrosa MC, Pfau PR, Pleskow DK, Tokar JL, Wang A, Song LM, Rodriguez SA. Endoluminal bariatric techniques. Gastrointest Endosc. 2012;76(1):1-7.

43. Mitura K, Garnysz K. Tolerance of intragastric balloon and patient's satisfaction in obesity treatment. Wideochir Inne Tech Maloinwazyjne. 2015;10(3):445-9.

44. Milone M, Maietta P, Bianco P, Pisapia A, Gaudioso $D$, Coretti $G$, et al. An early onset of acute renal failure in a young woman with obesity and infertility who underwent gastric balloon positioning. A case report. G Chir. 2014;35(3/4):73-4.

45. Drozdowski $R$, Wyleżoł $M$, Frączek $M$, Hevelke $P$, Giaro M, Sobański P. Small bowel necrosis as a consequence of spontaneous deflation and migration of an air-filled intragastric balloon - a potentially life-threatening complication. Wideochir Inne Tech Maloinwazyjne. 2014;9(2):292-6.

Received in: 23/08/2017

Accepted for publication: 28/09/2017

Conflict of interest: none.

Source of funding: none.

\section{Mailing address:}

Alana Costa Borges

E-mail: dra_alanacb@yahoo.com.br /

dra_alanacb@yahoo.com.br 